\title{
The Methylation Patterns of the IGF2 and IGF2R Genes in Bovine Spermatozoa are not Affected by Flow-Cytometric Sex Sorting
}

\author{
JOSÉ O. CARVALHO, ${ }^{1}$ VALQUÍRIA A. MICHALCZECHEN-LACERDA, ${ }^{2}$ ROBERTO SARTORI, ${ }^{1}$ FERNANDA C. RODRIGUES, ${ }^{3}$ \\ OTÁVIO BRAVIM, ${ }^{2}$ MAURÍCIO M. FRANCO, ${ }^{3,4,5}$ AND MARGOT A.N. DODE ${ }^{4,5 *}$ \\ ${ }^{1}$ Department of Animal Science, ESALQ, University of São Paulo, Piracicaba, São Paulo, Brazil \\ ${ }^{2}$ Intitute of Biology, University of Brasília, Brasília, Brazil \\ ${ }^{3}$ School of Veterinary Medicine, University of Uberlândia, Uberlândia, Brazil \\ ${ }^{4}$ Laboratory of Animal Reproduction, Embrapa Genetic Resources and Biotechnology, Brasilia, Brazil \\ ${ }^{5}$ School of Agriculture and Veterinary, University of Brasília, Brasília, Brazil
}

\section{SUMMARY}

The objectives of this study were to investigate the effect of sexing by flow cytometry on the methylation patterns of the IGF2 and IGF2R genes. Frozen-thawed, unsorted, and sex-sorted sperm samples from four Nellore bulls were used. Each ejaculate was separated into three fractions: non-sexed (NS), sexed for X-sperm (SX), and sexed for Y-sperm (SY). Sperm were isolated from the extender, cryoprotectant, and other cell types by centrifugation on a 40:70\% Percoll gradient, and sperm pellets were used for genomic DNA isolation. DNA was used for analyses of the methylation patterns by bisulfite sequencing. Methylation status of the IGF2 and IGF2R genes were evaluated by sequencing 195 and 147 individual clones, respectively. No global differences in DNA methylation were found between NS, SX, and SY groups for the IGF2 $(P=0.09)$ or IGF2R genes $(P=0.38)$. Very specific methylation patterns were observed in the 25th and 26th CpG sites in the IGF2R gene. representing higher methylation in NS than in the SX and SY groups compared with the other $\mathrm{CpG}$ sites. Further, individual variation in methylation patterns was found among bulls. In conclusion, the sexsorting procedure by flow cytometry did not affect the overall DNA methylation patterns of the IGF2 and IGF2R genes, although individual variation in their methylation patterns among bulls was observed.

Mol. Reprod. Dev. 79: 77-84, 2012. (c) 2011 Wiley Periodicals, Inc.

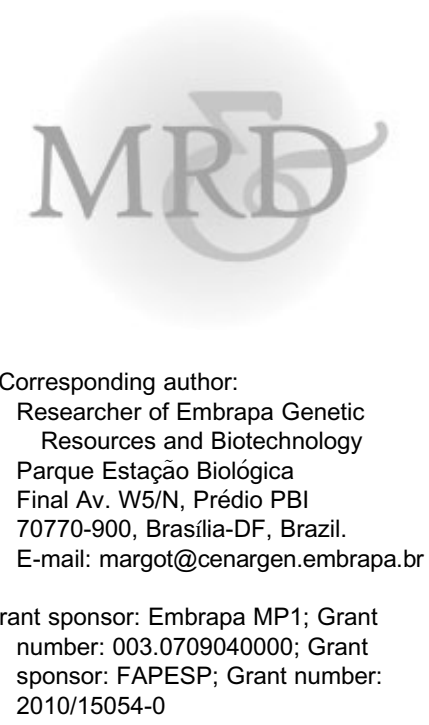

ESP; Grant number: 2010/15054-0

\section{INTRODUCTION}

Although sexed sperm can greatly impact on breeding programs, high cost and reduced pregnancy rates are limiting factors for wider application of this procedure in cattle breeding. Indeed, using sperm sexed by flow cytometry tends to result in low pregnancy rates in artificial insemination and embryo transfer programs (Seidel et al.,
1999; Sartori et al., 2004; Bodmer et al., 2005; Andersson et al., 2006; Peippo et al., 2009; Underwood et al., 2010ab), and low rates of in vitro embryo production (Morton et al.,

\footnotetext{
Abbreviations: DMR, differentially methylated region; ICR, imprinting control regions; IGF2[R], insulin-like growth factor 2 [receptor]; NS, non-sexed sperm; SX, sexed for X-sperm; SY, sexed for Y-sperm.
} 
2007; Bermejo-Alvarez et al., 2008, 2010). These results suggest that fluorescence-activated cell sorting using flow cytometry may damage sperm, which could be due to the exposure to the laser, high speeds inside the collecting tube, exposure of the droplets to electric charges, and/or incubation at room temperature while being processed. Besides affecting physical and structural characteristics of the sperm (Blondin et al., 2009; Carvalho et al., 2010), these factors are potential hazards to the DNA, which could affect subsequent embryo development.

Sperm DNA damage may result from DNA fragmentation, abnormal chromatin packaging, and epigenetic defects (Tavalaee et al., 2009). Yet, assessment of DNA fragmentation has been the only method used for evaluating the effect of sexing on chromatin integrity (Boe-Hansen et al., 2005; Blondin et al., 2009; Carvalho et al., 2010; Gosalvez et al., 2011), and no study has assessed possible epigenetic changes that could occur as well.

In mammals, correct DNA methylation reprogramming and maintenance of genomic imprinting during gametogenesis are essential for embryo development, normal preimplantation (Newell-Price et al., 2000), and maintenance of pregnancy (Lucifero et al., 2004). DNA methylation is one of the most stable epigenetic modifications, and is the most studied, major epigenetic modification governing gene expression (Bird, 2002; Jaenisch and Bird, 2003). It occurs in regions of the genome that are generally rich in $\mathrm{CpG}$ dinucleotides (Bird, 2002; Jaenisch and Bird, 2003), which are located on promoter regions in differentially methylated regions (DMR) or in imprinting control regions (ICR). DNA methylation is the most well-characterized example of epigenetic contribution of the sperm nucleus to the developing embryo, and paternal methylation defects can severely compromise embryo development (Carrel and Hammoud, 2010). This modification is thought to have dramatic impacts on embryo survival.

Two important imprinted genes are insulin-like growth factor 2 (IGF2) and insulin-like growth factor-2 receptor (IGF2R), which are, respectively, located on chromosome 29 and 9 in the bovine genome. Both genes are related to embryo development and placentation (Curchoe et al., 2005; Perecin et al., 2009). The /GF2 gene is predominantly expressed by the paternal allele and silenced on the maternal allele (Feil et al., 1994). This indicates the presence of an intragenic DMR, with a high level of DNA methylation in the sperm and a low level in the oocyte (Gebert et al., 2006). The IGF2R gene is generally imprinted on the paternally inherited allele and expressed from the maternal allele, and it is controlled by a differentially methylated ICR (Zwart et al., 2001).

There are a variety of studies reporting that artificial reproductive technologies (ARTs), including somatic cell nuclear transfer (SCNT), in vitro fertilization, intracellular sperm injection, cryopreservation, and in vitro embryo culture, are associated with changes in DNA methylation of the IGF2 and IGF2R imprinted genes (Curchoe et al., 2005; Long and Cai, 2007; Gebert et al., 2009; Poplinski et al., 2010). These changes can result in abnormal development because the acquisition and maintenance of genomic imprinting are critical for early embryogenesis and maintenance of pregnancy (Lucifero et al., 2004). The increase of the imprinting abnormalities in ARTs could arise from in vitro manipulation of gametes and embryos or other external factors, such as hormonal administration. Because sexsorted sperm are subjected to several hazardous conditions during the sorting process, we hypothesized that these factors may induce alterations in DNA methylation patterns. Therefore, this study investigated the effect of sexing by flow cytometry on the methylation patterns of the IGF2 and IGF2R genes.

\section{RESULTS}

Two imprinted genes that are normally paternally methylated (IGF2) or unmethylated (IGF2R) were examined using the quantitative bisulfite sequencing method. The methylation patterns of the IGF2 DMR and IGF2R ICR2 for all treatments are shown in Figure 1. One hundred percent of the analyzed sequences for the IGF2 or IGF2R genes in all treatments were hypermethylated ( $\geq 50 \%$ of $\mathrm{CpG}$ sites on a given methylated strand) or hypomethylated ( $<50 \%$ of $\mathrm{CpG}$ sites on a given methylated strand), respectively. For the IGF2 gene, 195 clones were evaluated, and in each clone, we analyzed a total of 28 CpG sites. No differences in DNA methylation were found between the non-sexed (NS) $(96.4 \pm 0.41 \% ; n=67$ clones), sexed for $X(S X)(95.4 \pm 0.46 \% ; n=67$ clones), and sexed for $\mathrm{Y}$ (SY) $(96.9 \pm 0.38 \% ; \mathrm{n}=61$ clones) sperm groups $(P=0.09)$.

For the IGF2R gene, 147 clones were evaluated, and for each clone a total of $26 \mathrm{CpG}$ sites were analyzed. Similar to the IGF2 gene, no differences in overall DNA methylation were found between the NS $(7.24 \pm 0.58 \% ; n=44$ clones $)$, SX $(8.0 \pm 0.64 \% ; n=58$ clones $)$, and SY $(7.96 \pm 0.46 \%$; $\mathrm{n}=48$ clones) groups $(P=0.38)$. Very specific methylation patterns were, however, observed in the 25th and 26th CpG sites (Fig. 1), which were highly methylated in the NS $(86.4 \%$ and $84.1 \%)$, SX $(86.2 \%$ and $81.0 \%)$, and SY (89.6\% and $62.5 \%)$ groups compared with the other CpG sites. Furthermore, the percentage of methylation on the 26th CpG site was lower $(P<0.05)$ in the SY group than in the NS and SX groups (Fig. 2).

We also compared the methylation patterns of the IGF2 and IGF2R genes among treatments for each individual bull, and among bulls within each treatment (Tables 1 and 2). For the IGF2 gene, there were no differences between bulls within the same group (Table 1). Bull 3 showed a difference in methylation patterns, with a higher percentage of methylation in the SY group than SX (Table 1 and Fig. 3). When the same analysis was performed for the IGF2R gene, there was no difference between sperm groups for any of the bulls (Table 2). Nevertheless, an effect by individual bull was observed on the methylation patterns of the IGF2R gene for the SY group, in which sperm from bulls 1 and 3 were less methylated than those from bulls 2 and 4 (Table 2 and Fig. 4). 

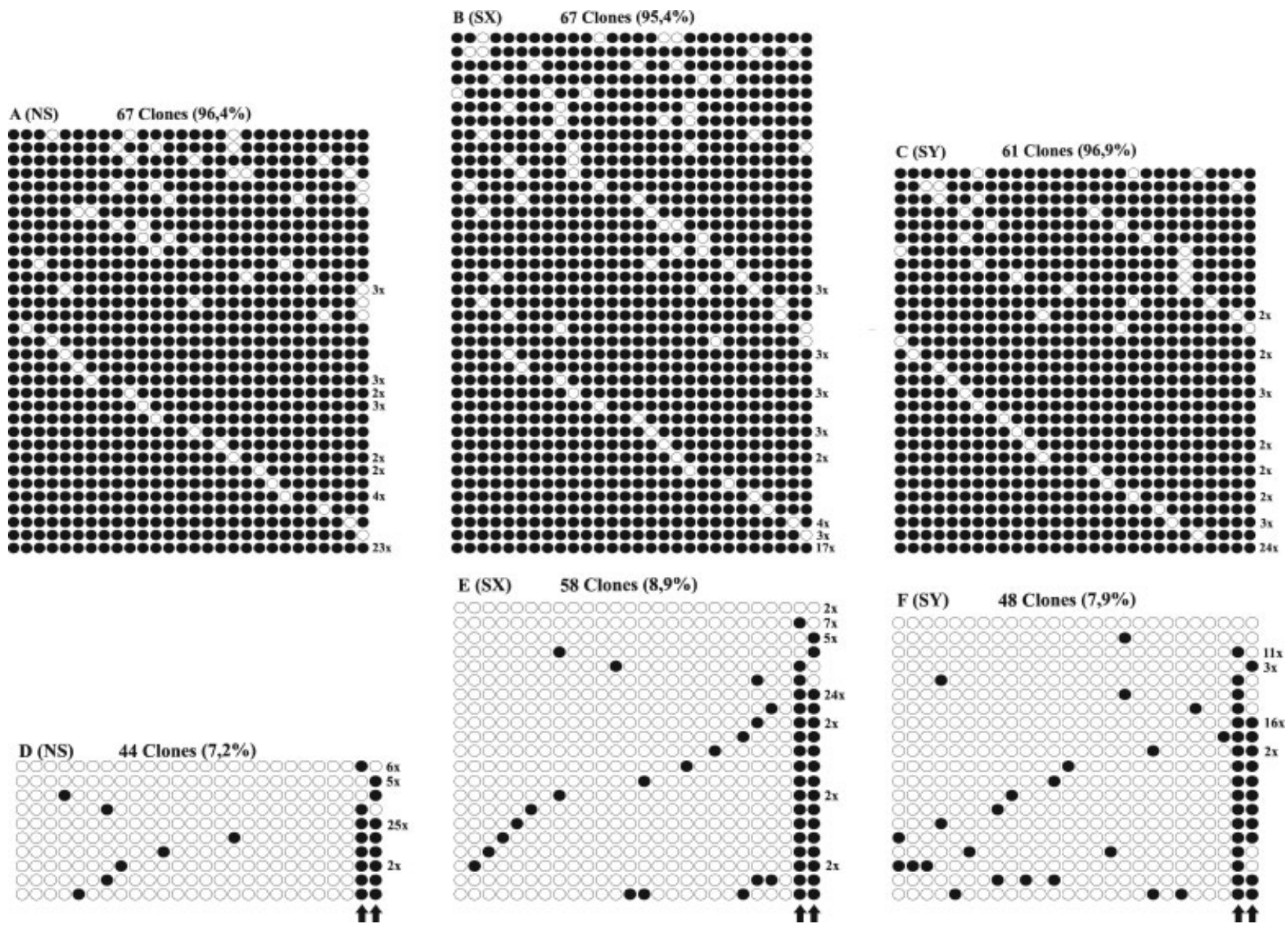

Figure 1. Methylation patterns in the DMR of the last exon of the /GF2 gene (A-C) and the second imprinting control region (ICR2) of the /GF2R gene (D-F) in non-sexed ( $A$ and $D)$, sexed-X ( $B$ and $\mathbf{E}$ ) and sexed-Y sperm ( $C$ and $F$ ) from four Nellore bulls. The arrow indicates the very specific methylation patterns observed in the 25th and 26th CpG sites, which had high methylation. White and dark circles represent unmethylated and methylated CpGs, respectively; horizontal lines of circles represent one clone, and the number of clones with the same methylation patterns is indicated at the right end of the lines. The data are the average of four bulls (three replicates per bull for the IGF2 gene, and two replicates per bull for the IGF2R gene).

\section{DISCUSSION}

During the sorting process, spermatozoa are exposed to several potential hazards that could be responsible for deleterious effects in the cell and reduced fertility rates. Indeed, some studies (Blondin et al., 2009; Carvalho et al., 2010) have focused on clarifying the effect of flow cytometric cell sorting on the viability of sperm cells. Several attributes of the spermatozoa, such as motility pattern, lifespan, acrosome integrity, viability of the plasma membrane, chromatin integrity, embryo development, and mRNA profile, have been evaluated (Boe-Hansen et al., 2005; Morton et al., 2007; Blondin et al., 2009; Carvalho et al., 2010); none of the studies have evaluated epigenetic changes-another candidate, given that cells susceptible to environmental changes are exposed to potential external risks.

Our results showed no differences in DNA methylation between the NS, SX, and SY groups for either gene (Fig. 1).
All analyzed sequences for the IGF2 and IGF2R genes in every treatment were hypermethylated and hypomethylated, respectively. These patterns of methylation for those specific regions in non-sexed (NS) bovine sperm have been described by Gebert et al. (2006), Long and Cai (2007), and Gebert et al. (2009).

Sexed sperm are subjected to a variety of adverse conditions during sorting, which can cause damage that may compromise embryo development and pregnancy rates. Previous studies in our laboratory have failed to detect an effect of sperm sexing on in vitro embryo development until D7 (Carvalho et al., 2010). We hypothesized that sex-sorting could cause sperm damage that is not observed in D7 embryos, but appears later in pregnancy; this possibility is supported by higher embryo loss between days 30 and 90 of pregnancy reported when sexed-sperm were used to inseminate cows and heifers (Bodmer et al., 2005). Embryonic loss between days 30 and 90 is also very common in cloned embryos (Hill et al., 2000; 


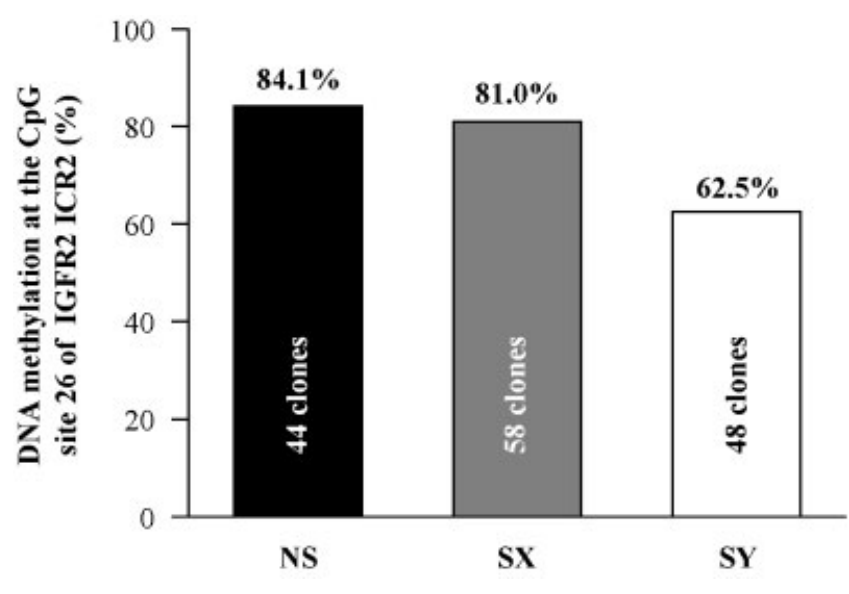

Figure 2. Percentage of methylation at the 26th $\mathrm{CpG}$ site in the second imprinting control region (ICR2) for the IGF2R gene in nonsexed (NS), sexed-X (SX), and sexed-Y $(S Y)$ bovine sperm $(P<0.05)$. Data are the average of four bulls (two replicates per bull).

Suteevun-Phermthai et al., 2009), perhaps due to abnormalities of DNA methylation in nuclear reprogramming during cloning (Kang et al., 2001; Young et al., 2001; Long and Cai, 2007). In that regard, abnormal methylation levels in sexed sperm could explain some of the problems with embryo development and implantation failures.

Based on these observations from embryo cloning, our finding that sperm sexing had no effect on methylation patterns of those regions was unexpected. We instead speculate that bovine sperm are highly resistant to DNA damage or environmental changes. It is well known that sperm DNA is extremely stable because the paternal genome is packaged and covalently modified (Hammoud et al., 2009a). This packaging in sperm DNA is supported by the high proportion of protamine proteins, with only a small portion of the DNA being associated with histone proteins (Hammoud et al., 2009a). Hammoud et al. (2009a) suggested that these remaining histones are associated with regions containing imprinted genes in bovine. Although both genes evaluated in this study are imprinted, it is not known whether these regions are packaged by histones or protamines, making these regions more or less susceptible to changes. Moreover, it is important to point out that in the present study we only assessed two regions of the genome, and we cannot assume that other regions do not have altered patterns of methylation due to sexing. Additionally, we cannot ignore that the sexing process has been improved in recent years (Sharpe and Evans, 2009), becoming more efficient and causing less damage to sperm. This is supported by recent studies that reported similar structural and/or functional quality in sorted and nonsorted bull sperm (Blondin et al., 2009; Peippo et al., 2009; Carvalho et al., 2010).

Notably, a very specific methylation patterns was observed in the 25th and 26th CpG sites of the IGF2R gene (Fig. 1). Evaluating the same region of the IGF2R gene in Bos taurus spermatozoa, Long and Cai (2007) found the same overall low methylation patterns as we did, but they did not observe hypermethylated patterns at these sites. Differences in methylation of specific $\mathrm{CpG}$ sites within the same region were also identified in other cell types and other genes (Kovacheva et al., 2007; Colosimo et al., 2009). We do not know the exact cause for specific CpG sites to be methylated, nor the biological implication of differential methylation patterns. One possibility that may explain the presence of high methylation in the IGF2R gene in our study is a specific epigenetic characteristic of Bos indicus compared to Bos taurus cattle. Furthermore, on the 26th $\mathrm{CpG}$ site, a difference in methylation was observed within treatments, with SY sperm having less methylation than the NS and SX sperm (Fig. 2). The reason why SY sexed sperm showed a lower resistance to demethylation of the IGF2R gene is not known.

We also found a difference from other reports in the number of $\mathrm{CpG}$ sites in the IGF2 gene. After DNA sequencing, we identified $28 \mathrm{CpG}$ sites in each clone evaluated, which was different from the $27 \mathrm{CpGs}$ reported by Gebert et al. (2006) and GenBank accession no. X53553. In a study conducted in our laboratory, Fagundes et al. (2011) evaluated the methylation patterns of immature and mature bovine oocytes, and identified the same difference in the number of CpGs in relation to the study of Gebert et al. (2006). This difference may be due to the presence of a single nucleotide polymorphism. We speculate that this difference occurred because each study used a distinct genetic group of cattle (Bos taurus vs. Bos indicus). These results lead us to believe that the differences in methylation

TABLE 1. Percentage of Methylation in the Last Exon of the IGF2 Gene in Non-Sexed (NS), Sexed X (SX), and Sexed Y (SY) Bovine Sperm From Four Different Bulls

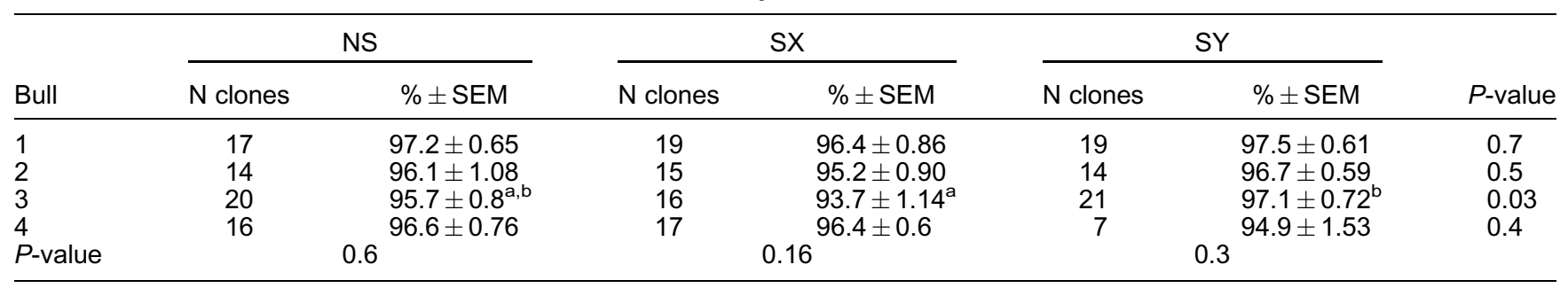

Data are the average of three replicates per bull.

a,b Within a line means without a common superscript difference $(P<0.05)$. 
TABLE 2. Percentage of Methylation in the Imprinting Control Region (ICR2) of the IGF2R Gene in Non-Sexed (NS), Sexed X (SX), and Sexed Y (SY) Bovine Sperm From Four Different Bulls

\begin{tabular}{|c|c|c|c|c|c|c|c|}
\hline \multirow[b]{2}{*}{ Bull } & \multicolumn{2}{|c|}{ NS } & \multicolumn{2}{|c|}{$s x$} & \multicolumn{2}{|c|}{ SY } & \multirow[b]{2}{*}{$P$-value } \\
\hline & $\mathrm{N}$ clones & $\% \pm$ SEM & $\mathrm{N}$ clones & $\% \pm$ SEM & $\mathrm{N}$ clones & $\% \pm$ SEM & \\
\hline $\begin{array}{l}1 \\
2 \\
3 \\
4 \\
P \text {-value }\end{array}$ & $\begin{array}{r}10 \\
18 \\
4 \\
12\end{array}$ & $\begin{array}{r}6.5 \pm 2.75 \\
8.0 \pm 0.39 \\
7.69 \pm 0.40 \\
6.73 \pm 0.83\end{array}$ & $\begin{array}{l}16 \\
15 \\
17 \\
10\end{array}$ & $\begin{array}{l}6.7 \pm 0.74 \\
7.4 \pm 0.79 \\
9.1 \pm 1.04 \\
8.8 \pm 1.00\end{array}$ & $\begin{array}{r}18 \\
7 \\
11 \\
12\end{array}$ & $\begin{array}{r}6.1 \pm 0.74^{\mathrm{a}} \\
9.9 \pm 1.85^{\mathrm{b}} \\
6.4 \pm 0.58^{\mathrm{a}} \\
9.61 \pm 1.30^{\mathrm{b}}\end{array}$ & $\begin{array}{l}0.28 \\
0.47 \\
0.13 \\
0.14\end{array}$ \\
\hline
\end{tabular}

Data are the average of two replicates per bull.

a,b Within a column means without a common superscript difference $(P<0.05)$.

\section{A (NS) 20 Clones}

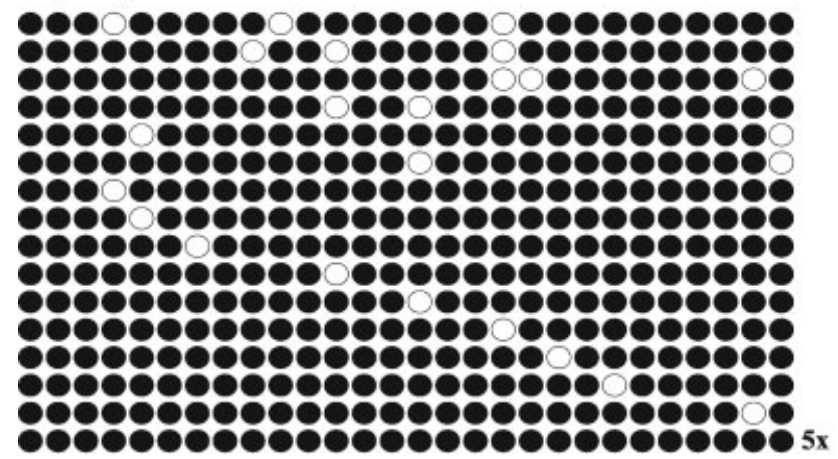

$\mathbf{B}(\mathbf{S X})$

16 Clones

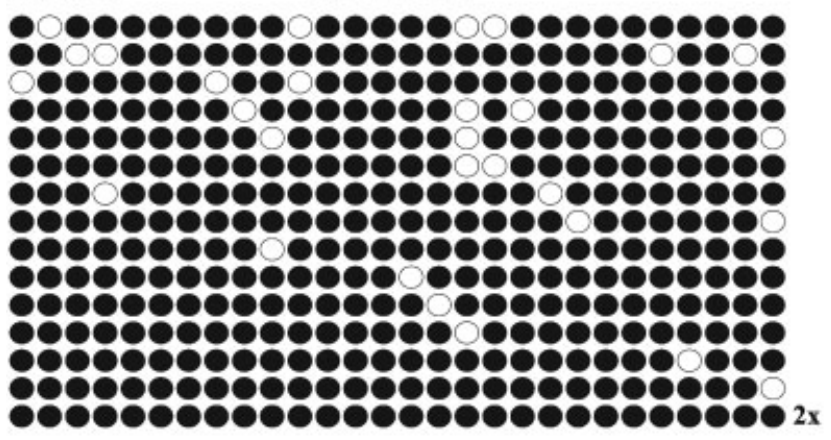

C (SY)

\section{Clones}

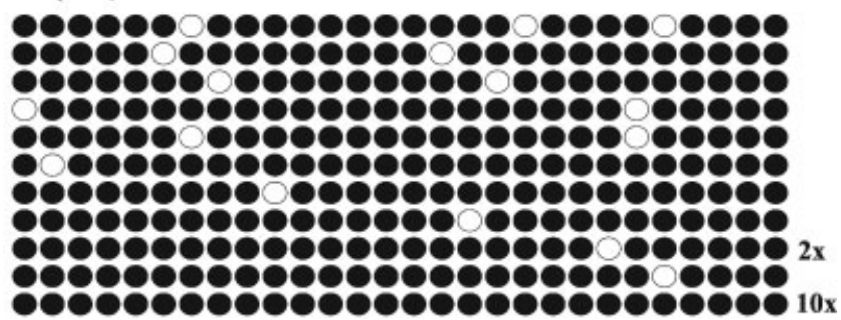

Figure 3. Methylation patterns in the last exon of the IGF2 gene in non-sexed (A), sexed-X (B), and sexed-Y sperm (C) from bull 3. White and dark circles represent unmethylated and methylated CpGs, respectively; horizontal lines of circles represent one clone, and the number of clones with the same methylation patterns is indicated at the right end of the lines. Data are the average of three replicates per group. of specific $\mathrm{CpG}$ sites and the difference in number of $\mathrm{CpG}$ sites in the studied regions may have some biological effect in the development of the embryo or even in the adult animal. This hypothesis is based on the several physiological differences reported between Bos taurus and Bos indicus, such as differences in ovarian function and in circulating hormones (Sartori and Barros, 2011). These differences could be due to epigenetic variation between the two subspecies.

When we evaluated the effect of sexing on methylation patterns of each individual bull within a treatment, only a slight difference was observed between groups. The difference in the methylation patterns found in bull 3 (Table 1; Fig. 3) or the SY group (Table 2; Fig. 4) for the IGF2 and IGF2R genes, in spite of being statistically significant, was so small that it likely has no biological effect. We believe that variation found in the methylation patterns can be attributed to individual characteristics of the bulls.

In conclusion, our study showed that sex-sorting by flow cytometry did not affect the DNA methylation patterns in the intragenic DMR located in the last exon of the IGF2 gene or the second ICR of the IGF2R gene. Yet, individual bull methylation variation was found. Furthermore, a very specific methylation patterns was observed in the IGF2R gene, probably due to an epigenetic characteristic in Bos indicus cattle.

\section{MATERIALS AND METHODS}

\section{Semen Collection and Sorting}

The semen used in this study was obtained from four sexually mature Nellore bulls. One ejaculate from each bull was collected by artificial vagina, and only ejaculates with $>60 \%$ motility and $<20 \%$ morphological abnormalities were used. Each ejaculate was divided into three fractions. One fraction was used as the non-sexed (NS) semen and the other two were subjected to flow cytometry and sorted for $X(S X)$ and $Y(S Y)$ fractions. The proportion of semen designated for immediate freezing was diluted in a Tris-base freezing diluent with $4 \%$ egg yolk, cooled at $4^{\circ} \mathrm{C}$ for $90 \mathrm{~min}$, and then diluted with the Bioxcell ${ }^{\circledR}$ (IMV, L'Aigle, France). Sperm were loaded into 0.5-ml straws (IMV, L'Aigle, France) and frozen in a programmable freezer TK $3000^{\circledR}$ (TK, Uberaba, MG, Brazil). At the end of 

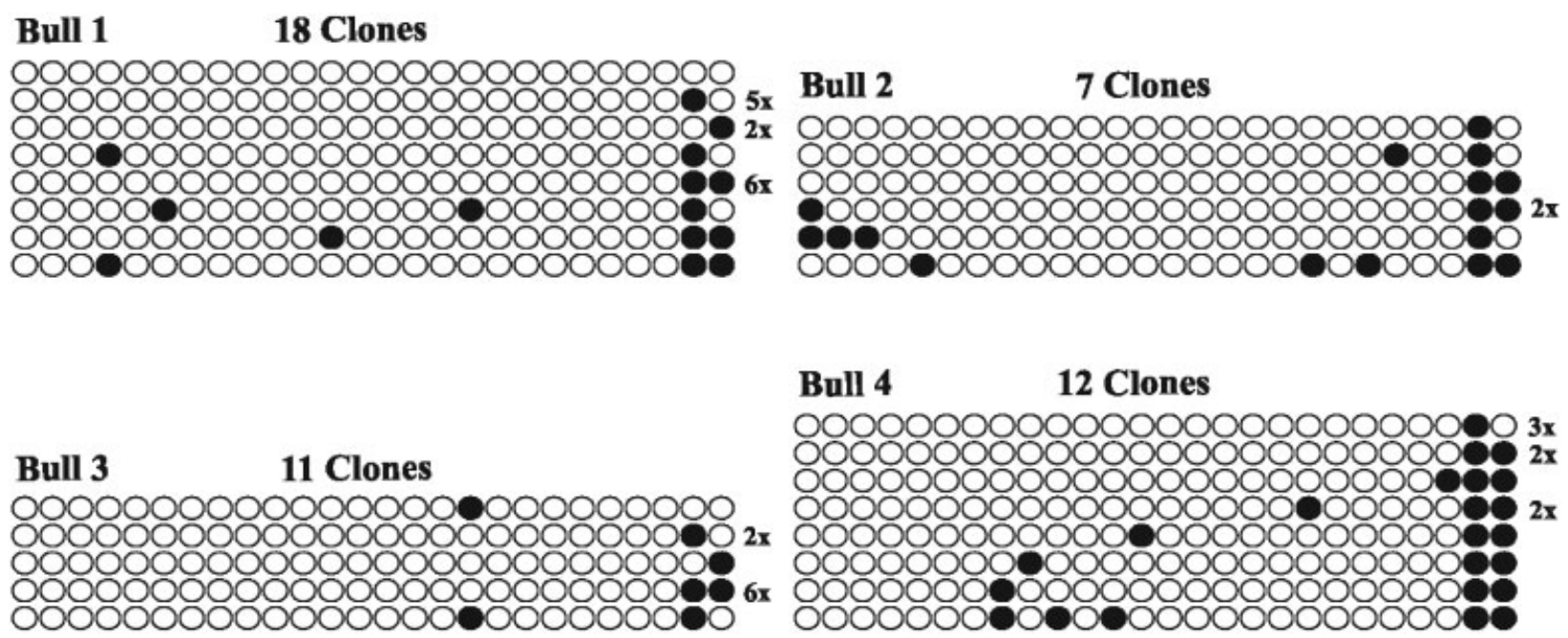

Figure 4. Methylation patterns in the second imprinting control region (ICR2) of the IGF2R gene in sexed-Y sperm from four Nellore bulls. White and dark circles represent unmethylated and methylated CpGs, respectively; horizontal lines of circles represent one clone, and the number of clones with the same methylation patterns is indicated at the right end of the lines. Data are the average of two replicates per bull.

the program, the straws were plunged into liquid nitrogen for storage.

The remainder of the ejaculate was diluted to $200 \times 10^{6} \mathrm{sperm} / \mathrm{ml}$ with Tris medium supplemented with 49-65 mM Hoechst 33342 (Invitrogen Molecular Probes ${ }^{\circledR}$, Eugene, OR) and incubated for $45 \mathrm{~min}$ at $35^{\circ} \mathrm{C}$. After staining, samples were diluted at $1: 1$ with Tris medium supplemented with $4 \%$ egg yolk and $0.0015 \%$ food dye (FD\&C \#40; Warner Jenkinson Company Inc., St. Louis, $\mathrm{MO}$ ), and filtered through a $50-\mu \mathrm{m}$ filter (GCAT, Fort Collins, CO) to remove any debris or agglutinated cells prior to sorting.

A high-speed cell sorter (MoFlo SX, Beckman Coulter, Fullerton, CA) was operated at 40 psi with a diode pumped solid-state pulse laser (Vanguard 350 HMD-355; Spectra Physics, Mountain View, CA) at $125 \mathrm{~mW}$ with bovine sheath fluid (CHATA Biosystems Inc., Fort Collins, CO). Gates were set to attain $90 \%$ purity, and sexed sperm were sorted into Tris medium. After cooling at $4^{\circ} \mathrm{C}$ for $90 \mathrm{~min}$, the sexed sperm was centrifuged and diluted in Bioxcell ${ }^{\circledR}$ (IMV, L'Aigle, France). The semen was packaged into $0.25 \mathrm{ml}$ straws and frozen as described above for non-sexed sperm.

\section{Sperm Processing}

Sperm cells were isolated from the extender, cryoprotectant, and other cell types by centrifugation on discontinuous density Percoll gradients (GE Healthcare Bio Science, Upsala, Sweden), as described by Lalancette et al. (2008). Briefly, one straw per group/bull was thawed and layered on top of a gradient composed of $2 \mathrm{ml} \mathrm{40:70 \%}$ Percoll and centrifuged for $45 \mathrm{~min}$ at $700 \times g$ at room temperature.

\section{DNA Isolation}

Genomic DNA was isolated from the pellet obtained after passage through a Percoll gradient using the Salting out procedure. Briefly, $300 \mu$ l of a lysis solution ( $50 \mathrm{mM}$ Tris, $\mathrm{pH}$ 7.8, $5 \mathrm{mM}$ EDTA, pH 8.0, $100 \mathrm{mM} \mathrm{NaCl}$, and 2\% SDS) with proteinase $\mathrm{K}(0.5 \mathrm{mg} / \mathrm{ml})$ and $0.3 \% \beta$-mercaptoethanol was added to the sperm pellet. The lysis proceeded overnight at $55^{\circ} \mathrm{C}$. Genomic DNA was separated using a $6 \mathrm{M} \mathrm{NaCl}$ solution and precipitated using isopropanol. The DNA pellet was washed with $1 \mathrm{ml} 70 \%$ ethanol followed by air-drying. The DNA was resuspended in about $50 \mu$ sterile water. Finally, the DNA was stored at $-80^{\circ} \mathrm{C}$ until needed for sodium bisulfite treatment.

\section{Sodium Bisulfite Treatment}

Genomic DNA (80-200 ng) treatment with sodium bisulfite was performed using the EZ DNA methylation kit (Zymo Research, Irvine, CA) according to the manufacturer's protocol, except that the conversion temperature was changed to $55^{\circ} \mathrm{C}$. Samples were diluted in $10 \mu \mathrm{l}$ of distilled water and maintained at $-80^{\circ} \mathrm{C}$ until needed for PCR amplification.

\section{PCR Amplification, Cloning, and Bisulfite Sequencing}

Nested PCR using bisulfite-treated DNA was performed to amplify a DMR located into the last exon of the IGF2 gene and an ICR located in intron 2 of the IGF2R gene. The primers used for IGF2 were designed by Gebert et al. (2006), and PCR was performed using $1 \times$ Taq buffer (Invitrogen, São Paulo, Brazil), $2.0 \mathrm{mM} \mathrm{MgCl}_{2}, 0.4 \mathrm{mM}$ 
dNTP, 10 pmoles of each primer, $1 \cup$ Platinum Taq Polymerase (Invitrogen), $3 \mu \mathrm{l}$ template DNA for the first round, and $0.5 \mu \mathrm{l}$ template DNA for the second round, in a total volume of $20 \mu \mathrm{l}$. Both rounds of nested PCR were carried out with an initial denaturing step of $94^{\circ} \mathrm{C}$ for $3 \mathrm{~min}$, and then 45 cycles at $94^{\circ} \mathrm{C}$ for $40 \mathrm{sec}, 45^{\circ} \mathrm{C}$ (first round) or $40^{\circ} \mathrm{C}$ (second round) for $1 \mathrm{~min}$, and $72^{\circ} \mathrm{C}$ for $1 \mathrm{~min}$, with a final extension at $72^{\circ} \mathrm{C}$ for $15 \mathrm{sec}$. For the IGF2R gene, the outer primers were designed according to Long and Cai (2007), and we designed the inner primers: forward $5^{\prime} \mathrm{AAAT}$ GAAAGYAGTGAATTA $3^{\prime}$ and reverse $5^{\prime}$ CCAACCRAACCRCTAACCCT $3^{\prime}$. PCR was performed using $1 \times$ Taq buffer (Invitrogen), $2.0 \mathrm{mM} \mathrm{MgCl}_{2}, 0.4 \mathrm{mM}$ dNTP, 10 pmoles of primer, $1 \mathrm{U}$ Platinum Taq Polymerase (Invitrogen), $3 \mu \mathrm{l}$ template DNA for the first round, and $0.5 \mu \mathrm{l}$ template DNA for the second round in a total volume of $20 \mu \mathrm{l}$. Both rounds of nested PCR were carried out with an initial denaturing step of $94^{\circ} \mathrm{C}$ for $3 \mathrm{~min}$ and then 15 cycles at $94^{\circ} \mathrm{C}$ for $40 \mathrm{sec}, 55^{\circ} \mathrm{C}$ (first round) or $50^{\circ} \mathrm{C}$ (second round) for $1 \mathrm{~min}$, and $72^{\circ} \mathrm{C}$ for $1 \mathrm{~min}$. Next, 20 more cycles were performed at $94^{\circ} \mathrm{C}$ for $40 \mathrm{sec}, 50^{\circ} \mathrm{C}$ (first round) or $45^{\circ} \mathrm{C}$ (second round) for $1 \mathrm{~min}$ and $72^{\circ} \mathrm{C}$ for $1 \mathrm{~min}$, with a final extension at $72^{\circ} \mathrm{C}$ for $15 \mathrm{sec}$. The PCR products were recovered from an agarose gel and purified using the GenClean III kit (MP Biomedicals, Solon, $\mathrm{OH}$ ) according to the manufacturer's protocol. Then, the purified products were cloned into the pGEMT-Easy vector (Promega) and transformed into Escherichia coli cells (XL-1 Blue).

Individual clones were sequenced using a dideoxy fluorescence terminator system (ABI $3130 x \mathrm{x})$. Only sequences originated from clones with $\geq 95 \%$ cytosine conversion were used. For each bull three (IGF2) and two (IGF2R) independent series of DNA extraction, amplification, cloning, and sequencing were carried out. Methylation status was determined by the BiQ Analyzer software (Bock et al., 2005 ) using the sequences in GeneBank (accession no. NM_174087.3 and no. DQ835615 for the IGF2 and IGF2R genes, respectively). Percentages of methylation were calculated by counting the number of methylated $\mathrm{CpGs}$ out of the total number of $\mathrm{CpG}$ sites in each clone.

\section{Statistical Analysis}

The methylation patterns of the different treatments (NS, SX and SY) and different bulls (1, 2, 3, and 4) were compared using the Kruskal-Wallis test in the Prophet Program, version 5.0 (BBN Systems and Technologies, 1996). The methylation patterns for the 25th and 26th CpG sites of IGF2R were analyzed using the Chi-square test. Data are presented as mean \pm SEM. A $P$-value of $<0.05$ was considered significant.

\section{ACKNOWLEDGMENTS}

This research was funded by Embrapa and FAPESP of Brazil. We thank FAPESP for financial support for the first author.

\section{REFERENCES}

Andersson M, Taponen J, Kommeri M, Dahlbom M. 2006. Pregnancy rates in lactating Holstein-Friesian cows after artificial insemination with sexed sperm. Reprod Domest Anim 41: 95-97.

Bermejo-Alvarez P, Lonergan P, Rath D, Gutierrez-Adan A, Rizos D. 2010. Developmental kinetics and gene expression in male and female bovine embryos produced in vitro with sex-sorted spermatozoa. Reprod Fertil Dev 22:426436.

Bermejo-Alvarez P, Rizos D, Rath D, Lonergan P, Gutierrez-Adan A. 2008. Can bovine in vitro-matured oocytes selectively process X- or Y-sorted sperm differentially? Biol Reprod 79: 594-597.

Bird A. 2002. DNA methylation patterns and epigenetic memory. Genes Dev 16:6-21.

Blondin P, Beaulieu M, Fournier V, Morin N, Crawford L, Madan P, King WA. 2009. Analysis of bovine sexed sperm for IVF from sorting to the embryo. Theriogenology 71:30-38.

Bock C, Reither S, Mikeska T, Paulsen M, Walter J, Lengauer T. 2005. BiQ Analyzer: Visualization and quality control for DNA methylation data from bisulfite sequencing. Bioinformatics 21: 4067-4068.

Bodmer M, Janett F, Hassig M, den Daas N, Reichert P, Thun R. 2005. Fertility in heifers and cows after low dose insemination with sex-sorted and non-sorted sperm under field conditions. Theriogenology 64:1647-1655.

Boe-Hansen GB, Morris ID, Ersboll AK, Greve T, Christensen P. 2005. DNA integrity in sexed bull sperm assessed by neutral Comet assay and sperm chromatin structure assay. Theriogenology 63:1789-1802.

Carrel DT, Hammoud SS. 2010. The human sperm epigenome and its potential role in embryonic development. Mol Hum Reprod 16:37-47.

Carvalho JO, Sartori R, Machado GM, Mourao GB, Dode MA. 2010. Quality assessment of bovine cryopreserved sperm after sexing by flow cytometry and their use in in vitro embryo production. Theriogenology 74:1521-1530.

Colosimo A, Di Rocco G, Curini V, Russo V, Capacchietti G, Berardinelli P, Mattioli M, Barboni B. 2009. Characterization of the methylation status of five imprinted genes in sheep gametes. Anim Genet 40:900-908.

Curchoe C, Zhang S, Bin Y, Zhang X, Yang L, Feng D, O'Neill M, Tian XC. 2005. Promoter-specific expression of the imprinted IGF2 gene in cattle (Bos taurus). Biol Reprod 73:12751281.

Fagundes NS, Michalczechen-Lacerda VA, Caixeta ES, Machado GM, Rodrigues FC, Melo EO, Dode MA, Franco MM. 2011. Methylation status in the intragenic differentially methylated region of the IGF2 locus in Bos taurus indicus oocytes with different developmental competencies. Mol Hum Reprod 17: 85-91. 
Feil R, Walter J, Allen ND, Reik W. 1994. Developmental control of allelic methylation in the imprinted mouse Igf2 and $\mathrm{H} 19$ genes. Development 120:2933-2943.

Gebert C, Wrenzycki C, Herrmann D, Groger D, Reinhardt R, Hajkova P, Lucas-Hahn A, Carnwath J, Lehrach H, Niemann H. 2006. The bovine IGF2 gene is differentially methylated in oocyte and sperm DNA. Genomics 88:222-229.

Gebert C, Wrenzycki C, Herrmann D, Groger D, Thiel J, Reinhardt $R$, Lehrach $H$, Hajkova $P$, Lucas-Hahn A, Carnwath JW, Niemann H. 2009. DNA methylation in the IGF2 intragenic DMR is re-established in a sex-specific manner in bovine blastocysts after somatic cloning. Genomics 94:63-69.

Gosalvez J, Ramirez MA, Lopez-Fernandez C, Crespo F, Evans KM, Kjelland ME, Moreno JF. 2011. Sex-sorted bovine spermatozoa and DNA damage: I. Static features. Theriogenology 75 : 197-205.

Hammoud S, Liu L, Carrell DT. 2009a. Protamine ratio and the level of histone retention in sperm selected from a density gradient preparation. Andrologia 41:88-94.

Hammoud SS, Nix DA, Zhang H, Purwar J, Carrell DT, Cairns BR. $2009 \mathrm{~b}$. Distinctive chromatin in human sperm packages genes for embryo development. Nature 460:473-478.

Hill JR, Burghardt RC, Jones K, Long CR, Looney CR, Shin T, Spencer TE, Thompson JA, Winger QA, Westhusin ME. 2000. Evidence for placental abnormality as the major cause of mortality in first-trimester somatic cell cloned bovine fetuses. Biol Reprod 63:1787-1794.

Jaenisch R, Bird A. 2003. Epigenetic regulation of gene expression: how the genome integrates intrinsic and environmental signals. Nat Genet 33:245-254.

Kang YK, Koo DB, Park JS, Choi YH, Chung AS, Lee KK, Han YM. 2001. Aberrant methylation of donor genome in cloned bovine embryos. Nat Genet 28:173-177.

Kovacheva VP, Mellott TJ, Davison JM, Wagner N, Lopez-Coviella I, Schnitzler AC, Blusztajn JK. 2007. Gestational choline deficiency causes global and Igf2 gene DNA hypermethylation by up-regulation of Dnmt1 expression. J Biol Chem 282:3177731788.

Lalancette C, Thibault C, Bachand I, Caron N, Bissonnette N. 2008. Transcriptome analysis of bull semen with extreme nonreturn rate: use of suppression-subtractive hybridization to identify functional markers for fertility. Biol Reprod 78:618-635.

Long JE, Cai X. 2007. Igf-2r expression regulated by epigenetic modification and the locus of gene imprinting disrupted in cloned cattle. Gene 388:125-134.

Lucifero D, Mann MR, Bartolomei MS, Trasler JM. 2004. Genespecific timing and epigenetic memory in oocyte imprinting. Hum Mol Genet 13:839-849.

Morton KM, Herrmann D, Sieg B, Struckmann C, Maxwell WM, Rath D, Evans G, Lucas-Hahn A, Niemann H, Wrenzycki C. 2007. Altered mRNA expression patterns in bovine blastocysts after fertilisation in vitro using flow-cytometrically sex-sorted sperm. Mol Reprod Dev 74:931-940.
Newell-Price J, Clark AJ, King P. 2000. DNA methylation and silencing of gene expression. Trends Endocrinol Metab 11: 142-148.

Peippo J, Vartia K, Kananen-Anttila K, Raty M, Korhonen K, Hurme T, Myllymaki H, Sairanen A, Maki-Tanila A. 2009. Embryo production from superovulated Holstein-Friesian dairy heifers and cows after insemination with frozen-thawed sex-sorted $x$ spermatozoa or unsorted semen. Anim Reprod Sci 111:80-92.

Perecin F, Méo SC, Yamazaki W, Ferreira CR, Merighe GKF, Meirelles FV, Garcia JM. 2009. Imprinted gene expression in in vivo- and in vitro-produced bovine embryos and chorioallantoic membranes. Genet Mol Res 8:76-85.

Poplinski A, Tuttelmann F, Kanber D, Horsthemke B, Gromoll J. 2010. Idiopathic male infertility is strongly associated with aberrant methylation of MEST and IGF2/H19 ICR1. Int J Androl 33:642-649.

Rosenfeld CS. 2010. Animal models to study environmental epigenetics. Biol Reprod 82:473-488.

Sartori R, Barros CM. 2011. Reproductive cycles in Bos indicus cattle. Anim Reprod Sci 21:21.

Sartori R, Souza AH, Guenther JN, Caraviello DZ, N GL, Schenk JL, Wiltbank MC. 2004. Fertilization rate and embryo quality in superovulated Holstein heifers artificially inseminated with X-sorted or unsorted sperm. Anim Reprod 1:86-90.

Seidel GE, Jr, Schenk JL, Herickhoff LA, Doyle SP, Brink Z, Green RD, Cran DG. 1999. Insemination of heifers with sexed sperm. Theriogenology 52:1407-1420.

Sharpe JC, Evans KM. 2009. Advances in flow cytometry for sperm sexing. Theriogenology 71:4-10.

Suteevun-Phermthai T, Curchoe CL, Evans AC, Boland E, Rizos D, Fair T, Duffy P, Sung LY, Du F, Chaubal S, Xu J, Wechayant T, Yang X, Lonergan P, Parnpai R, Tian XC. 2009. Allelic switching of the imprinted IGF2R gene in cloned bovine fetuses and calves. Anim Reprod Sci 116:19-27.

Tavalaee M, Razavi S, Nasr-Esfahani MH. 2009. Influence of sperm chromatin anomalies on assisted reproductive technology outcome. Fertil Steril 91:1119-1126.

Underwood SL, Bathgate R, Ebsworth M, Maxwell WM, Evans G. 2010a. Pregnancy loss in heifers after artificial insemination with frozen-thawed, sex-sorted, re-frozen-thawed dairy bull sperm. Anim Reprod Sci 118:7-12.

Underwood SL, Bathgate R, Maxwell WM, Evans G. 2010b. Birth of offspring after artificial insemination of heifers with frozenthawed, sex-sorted, re-frozen-thawed bull sperm. Anim Reprod Sci 118:171-175.

Young LE, Fernandes K, McEvoy TG, Butterwith SC, Gutierrez CG, Carolan C, Broadbent PJ, Robinson JJ, Wilmut I, Sinclair KD. 2001. Epigenetic change in IGF2R is associated with fetal overgrowth after sheep embryo culture. Nat Genet 27:153-154.

Zwart R, Sleutels F, Wutz A, Schinkel AH, Barlow DP. 2001. Bidirectional action of the Igf2 $r$ imprint control element on upstream and downstream imprinted genes. Genes Dev 15: 2361-2366. 